\title{
Политика ядерного сдерживания НАТО: Варшавский саммит и после него
}

\section{Мэттью П. Андерсон}

Европейский центр исследований безопасности имени Джорджа К. Маршалла, http://www.marshallcenter.org

Резюме: В обзоре НАТО состояния сдерживания и обороны (ОССО, 2012) сделан вывод, что «состояние ядерных сил Альянса в настоящее время соответствует критериям эффективного сдерживания и обороны». В дополнение к стратегическим ядерным силам Франции, Соединенного Королевства и Соединенных Штатов в охват «состояния» НАТО входят около 200 «тактических» ядерных бомб В-61, хранящихся на объектах в пяти государствах, являющихся давними членами союза. Со времени публикации ОССО отношения НАТО с Россией ухудшились. По всей видимости, американские ядерные заряды B-61, которые скоро подвергнутся усовершенствованию в рамках многомиллиардной программы по продлению срока жизни, обречены оставаться в Европе. Под спокойной поверхностью, однако, остаются тревожные вопросы о пресловутых трех моментах политики сдерживания НАТО - ее военных способностях, доверии к ней и ее коммуникации с потенциальными противниками и партнерами. В этой работе предлагается проведение шести реформ в политике ядерного сдерживания, которые НАТО следует рассмотреть после Варшавского саммита в июле 2016 для того, чтобы вернуть себе то доверие, которым оно пользовалось в период Холодной войны.

Ключевые слова: НАТО, Варшава, В-61, сдерживание, летательный аппарат двойного назначения, тактическое ядерное оружие. 


\section{Введение}

После окончания Холодной войны НАТО, со своей стороны, сознательно и демонстративно уменьшало значение ядерного оружия в своей оборонной политике и своем потенциале. В результате этого, сейчас у Альянса нет политики и способностей, необходимых для сдерживания, и если необходимо, для ответа на ограниченный ядерный удар со стороны России.

- Доктор Мэттью Крениг, 2015, показания в Сенате США ${ }^{1}$

Саммит НАТО в Варшаве в июле 2016 года дает еще одну возможность инициировать столь необходимый пересмотр ядерной политики Альянса. После окончания Холодной войны Альянс сместил фокус своей деятельности от коллективной обороны и сдерживания к операциям по менеджменту кризисов, что лучше всего было видно на Балканах и в Афганистане. В процессе этого многие утверждают, что НАТО начало пренебрегать традиционным ядерным сдерживанием после падения Берлинской стены двадцать пять лет тому назад. ${ }^{2}$ Однако, в 2014 году все переменилось. После незаконной аннексии Крыма и активной поддержки сепаратистов в Восточной Украине Россией НАТО заявило, что «агрессивные действия России против Украины фундаментально изменили наш взгляд на целостную, свободную и мирную Европу». ${ }^{3}$ Сирийская гражданская война (и связанный с ней европейский кризис с беженцами), нападения «Исламского государства» (ИГ) в Париже, Стамбуле и Брюсселе и сбитие Турцией российского истребителя заставили НАТО заняться проблемами безопасности как на Востоке, так и на Юге, проблемами, порожденными как государственными, так и негосударственными субъектами. Это означает, что НАТО разбрасывается на многих направлениях, тогда как Россия продолжает все более шумно бренчать своей ядерной саблей. Хотя последние реформы преобладали в заголовках публикаций, предшествовавших Варшавскому саммиту, в свете развивающихся событий надежность ядерного сдерживания, осуществляемого НАТО, остается под вопросом. Со своей стороны, это поднимает вопрос: что нужно сделать НАТО на саммите в Варшаве, чтобы определить и укрепить свою политику ядерного сдерживания?

НАТО следует рассмотреть следующие шесть изменений в своей политике ядерного сдерживания, которые одновременно обеспечат надежное сдерживание противника в двадцать первом веке и сплоченность членов

1 Matthew Kroenig, The Renewed Russian Nuclear Threat and NATO Nuclear Deterrence Posture (Washington, DC: Atlantic Council, 2016), по состоянию на 24 января 2016, http://www.atlanticcouncil.org/images/publications/Russian_Nuclear_Threat_ 0203_web.pdf.

2 Michael Rühle, The Broader Context of NATO's Nuclear Policy and Posture (Rome: NATO Defense College, 2013).

3 NATO, Wales Summit Declaration, September 5, 2014, по состоянию на 5 января 2016, http://www.nato.int/cps/en/natohq/official_texts_112964.htm. 
Альянса. Эти шесть изменений попадают в охват трех требований для обеспечения эффективного сдерживания: способностей, доверия и коммуникаций. ${ }^{4}$ В число шести рекомендаций входят:

- Расположение самолетов двойного назначения (СДН - несущих ядерное и неядерное оружие) и развертывание миссий ядерного удара в Польше и Турции;

- Включение Крыла тяжелого воздушного транспорта С-17 в Основное ядерное воздушно-транспортное соединение;

- Сохранение статус-кво в плане мест расположения и количества зарядов В-61;

- Повышение ядерной боеготовности (уменьшение времени реакции) баз с самолетами с двойным назначением;

- Создание «Фонда НАТО для ядерного сдерживания»;

- Составление проекта ядерной декларации НАТО.

\section{Новейшая ядерная история НАТО}

В отличие от Соединенных Штатов и НАТО, при планировании в сфере национальной безопасности после окончания Холодной войны Россия обращала особое внимание на ядерное оружие.

- Мэттью Крениг

В 1954 году впервые ядерные оружия Альянса были размещены в Европе, шаг, который был единодушно одобрен НАТО. ${ }^{5}$ В то время, задачей этого оружия было противодействие преобладающему конвенциональному превосходству Советского Союза над Альянсом. С тех пор количество и виды ядерного оружия в Европе сильно изменились. Однако, после 1991 года единственным американским ядерным оружием в Европе остались авиационные бомбы США В-61, спроектированные для сбрасывания с истребителей-бомбардировщиков "двойного назначения». ${ }^{6}$

Несмотря на лоббистские попытки некоторых союзников, которые хотят, чтобы В-61 были выведены из Европы, это вызывающее противоречия «тактическое» ядерное оружие осталось на континенте благодаря Обзору

4 Мистер Хайнрих Браус, помощник Генерального секретаря НАТО по вопросам оборонной политики и планирования, еще раз подчеркнул значение трех факторов сдерживания (способности, надежность и коммуникации) на симпозиуме по оборонному планирования в Школе НАТО в Обераммергау, 23-25 февраля 2016.

5 George Mindling and Robert Bolton, U.S. Air Force Tactical Missiles 1949-1969: The Pioneers (Morrisville, North Carolina: Lulu.com Publishing, 2011).

6 Hans Kristensen, U.S. Nuclear Weapons in Europe: A Review of Post-Cold War Policy, Force Levels and War Planning (Washington, DC: Natural Resources Defense Council, 2005). 
состояния сдерживания и обороны (ОССО) НАТО от 2012 года. ${ }^{7}$ Ульрих Кан объясняет, почему попытки лоббирования не сработали: «Они [попытки лоббирования] провалились, главным образом, из-за опасений восточных членов НАТО, которые придают высокое символическое/политическое значение единственному американскому ядерному оружию, расположенному в настоящее время в Европе». ${ }^{8}$ Кроме того, в январе 2014 Конгресс США предоставил полное финансирование в объеме 10 миллиардов долларов программы продления срока жизни В-61 путем их модернизации, причем ожидается, что новая версия (B-61, модификация 12) будет на месте в 2020 году. ${ }^{9}$ С учетом наличия модернизованного оружия, уже маячившего на горизонте, Турция, Италия и Нидерланды решили заменить свои самолеты двойного предназначения американским малозаметным истребителем-бомбардировщиком F-35. Что касается замены ударных платформ, однако, Бельгия и Германия все еще должны принять решение или декларировать твердую готовность. ${ }^{10}$

\section{Три столба текущей политики сдерживания НАТО}

ОССО основывался на двух принципах: во-первых, Россия является партнером НАТО, и во-вторых, она не будет применять против Альянса свои существенные запасы ядерного оружия в Европе. Оба эти предположения уже не верны.

- Карл-Хайнц Камп

\section{Изменившаяся среда безопасности}

Сегодня среда безопасности полностью отличается от той, с которой сталкивался Альянс в 2012 году, особенно в плане ядерного оружия. Опубликование ОССО НАТО в 2012 году положило конец спорам о выводе ядерного оружия США из Европы, начало которым в 2009 поставил Гуидо Вестервелле, бывший в то время министром иностранных дел Германии. Однако, по мнению Карл-Хайнц Кампа, академического директора Федеральной академии Германии по политике безопасности в Берлине, ОССО «основывался на двух принципах: во-первых, Россия является партнером НАТО, и во-вторых, она не будет применять против Альянса свои существенные запасы ядерного оружия в Европе. Оба эти предположения уже

7 “NATO's Nuclear Deterrence Policy and Forces," December 3, 2015, по состоянию на 5 января 2016, http://www.nato.int/cps/en/natohq/topics_50068.htm.

8 Ulrich Kühn, "With or Without You: Germany and NATO," War on the Rocks, November 3, 2015, по состоянию на 10 мая 2016, http://warontherocks.com/2015/11/ with-or-without-you-germany-and-nato/.

9 Ibid.

10 Hans Kristensen, "Polish F-16s in NATO Nuclear Exercise in Italy," Federation of American Scientists (FAS), October 27, 2014, по состоянию на 23 марта 2016, https://fas.org/blogs/security/2014/10/steadfastnoon/. 
не верны». ${ }^{11}$ Далее, в 2015 году Камп объяснял, что «российские вооруженные силы на учениях симулируют использование ядерного оружия против Польши, угрожают разместить баллистические ракеты в Калининграде и нарушают воздушное пространство НАТО полетами самолетов, способных нести ядерное оружие». ${ }^{12}$ Это особенно тревожно с учетом нынешней военной политики России, надзор над разработкой которой осуществлял Президент Путин и которую он подписал в 2000 году. «Согласно концепции «эскалировать, чтобы де-эскалировать», или концепции «контроля эскалации», Москва будет использовать угрозу нанесения, или даже нанесение ограниченных ядерных ударов в конвенциональном конфликте, чтобы заставить своих противников капитулировать на ее мирных условиях», ${ }^{13}$ объясняет Крениг. Эта меняющая правила игры политики де-эскалации, реализованная на практике в Украине и в Крыму, снова выводит ядерное сдерживание на первые места в повестке дня НАТО.

Точнее, среда безопасности, с которой сталкивается НАТО сегодня, в основном сфокусирована на угрозах из двух регионов: восточный фланг и южный фланг. Члены НАТО из Восточной Европы надеются, что Варшавский саммит будет, главным образом, заниматься реализацией и усовершенствованием военных способностей, соглашение о которых было достигнуто в Уэльсе в 2014 году для того, чтобы «усовершенствовать способности для сдерживания и обороны НАТО против России». ${ }^{14}$ В одном докладе корпорации РЭНД от февраля 2016 сделано заключение, что «Наступление России на территорию НАТО в Балтике сокрушило бы недостаточно хорошо вооруженные силы альянса в течение нескольких часов, поставив НАТО перед жесткой дилеммой: начать длительное, кровопролитное контрнаступление или признать поражение». ${ }^{15}$ Хотя южные страны-члены НАТО понимают озабоченность восточных членов, они не хотят, чтобы Альянс упускал из виду то, что НАТО называет «БВСА» (Ближний Восток и Северная Африка). ${ }^{16}$ Регион БВСА содержит такие угрозы, как "Исламское государство», провалившиеся государства и непрогнозируемое развитие кризиса с беженцами. Эти две основные проблемы, однако, не должны заслонять будущее политики НАТО по ядерному сдерживанию.

11 Karl-Heinz Kamp, "The Agenda of the NATO Summit in Warsaw" (working paper, Federal Academy for Security Policy, Berlin, 2015), по состоянию на 5 мая 2016, www.baks.bund.de/sites/baks010/files/working_paper_security_policy_9_2015.pdf. Там же.

13 Kroenig, The Renewed Russian Nuclear Threat and NATO Nuclear Deterrence Posture.

14 Kamp, "The Agenda of the NATO Summit in Warsaw."

15 John Vandiver, "Report: Russia Defeats NATO in Baltic War Game," Stars and Stripes, February 5, 2016, по состоянию на 6 мая 2016, http://www.military.com/dailynews/2016/02/05/report-russia-defeats-nato-in-baltic-war-game.html.

16 Kamp, "The Agenda of the NATO Summit in Warsaw." 


\section{Первый фактор: способности}

Первым фактором традиционного сдерживания является наличие соответствующих способностей. Точнее, военных способностей. Не стоит пытаться понять проблему сдерживания в ее целостности без того, чтобы сначала не пролить свет на конвенциональные (неядерные) и ядерные способности, которыми на данный момент располагает Альянс. Честно говоря, они оставляют желать лучшего. «При нынешнем состоянии, НАТО не может успешно защищать территорию своих членов, подвергающихся наибольшей опасности», ${ }^{17}$ сказано в исследовании РЭНД от 2016 года. С точки зрения НАТО, грань между конвенциональным и ядерным оружием в сегодняшней среде безопасности является, возможно, более четкой, чем прежде, во времена Холодной войны. Примером тому является факт, что НАТО уже не ссылается на «континуум», простирающийся между конвенциональной и ядерной войной. ${ }^{18}$ Однако, российская доктрина «эскалировать, чтобы де-эскалировать» размывает эту разделяющую линию. ${ }^{19}$ Ситуация сегодня насыщена такими серыми зонами, как гибридная война, кибервойна, современная концепция ПдПвП (предотвращение доступа и проникновения в воздушное пространство) и террористические нападения в диапазоне от захвата воздушных судов до химических, биологических, радиологических и ядерных (ХБРЯ) атак. В теории, во время войны, каждый из двадцати восьми союзников по НАТО предоставляет командование своими вооруженными силами Главнокомандующему объединенных сил в Европе (ГОСЕ). По традиции эту должность занимает четырех-звездный генерал или адмирал вооруженных сил США. На практике, политическое руководство каждой страны решает когда, где и в каком качестве будут развернуты их силы под флагом НАТО. Более десяти лет мы видим эту динамику в действии в Афганистане.

В плане целостного сдерживания, такая организация является проблематической, поскольку даже военные планировщики в Брюсселе не знают какими силами они будут располагать на данный конкретный момент времени. Хотя операции в Афганистане и на Балканах действительно отличаются от ситуации, когда может быть задействована Статья V, как в Балтике, они показали, что членам союза разрешено предоставлять свои силы «с оговорками» или ограничениями. Это создает проблемы в смысле удовлетворения требований миссии. Ревизионистский курс действий России на Востоке, однако, заставил Альянс осуществить небольшое число всеохватных изменений для того, чтобы любой потенциальный противник имел четкое представление о боевых способностях сил НАТО. Выступая на Конференции по безопасности в Мюнхене в феврале 2016 года, Генераль-

17 Vandiver, "Russia Defeats NATO in Baltic War Game."

18 Anthony Stroup (Chief, Nuclear, CBRN Defence and Arms Control Policy Branch, NATO International Military Staff), интервью автора, 6 мая 2016.

19 Kroenig, The Renewed Russian Nuclear Threat and NATO Nuclear Deterrence Posture. 
ный секретарь НАТО, Йенс Столтенберг, заявил, что перед лицом «более напористой России» НАТО необходимо «дать мощный сигнал, направленный на сдерживание любой агрессии или любого шантажа». ${ }^{20}$ После последнего саммита в 2014 году НАТО давало такие сигналы, в основном, с использованием конвенциональных средств.

\section{Конвенциональные средства}

В плане конвенциональных средств, деятельность НАТО после саммита в Уэльсе в 2014 была направлена на реализацию Плана действий по повышению боеготовности (ПДПБ). Союзники разработали ПДПБ, чтобы «уверить союзников на передовой линии, что НАТО хочет и может защитить их суверенитет от российской агрессии». ${ }^{21}$ НАТО описывает этот план как состоящий из двух основных элементов: 1) меры по гарантированию и 2) меры по адаптации. Меры по гарантированию охватывают действия, которые расширяют военное присутствие и военную деятельность в целях гарантирования и сдерживания, например, увеличение числа патрулирующих воздушное пространство истребителей в Балтике с четырех до шестнадцати. Меры по адаптации включают изменение долгосрочной военной политики и военных способностей, например, усиление ответной реакции и способностей Сил реагирования НАТО (СРН). ${ }^{22}$

В последнее время, в феврале 2016, НАТО приняло решение расширить своей присутствие путем создания многонациональных ротационных контингентов. Ротационные, или на языке НАТО «постоянно возобновляющиеся» силы, в отличие от «постоянно размещенных» сил, остаются в глазах Альянса - и в глазах Москвы - существенным моментом. В Основополагающем акте НАТО-Россия, подписанном за два года до того, как первые центрально-европейские и восточно-европейские (ЦВЕ) демократии присоединились к НАТО, сказано, что НАТО может защищать свою (расширенную) территорию без «дополнительного постоянного размещения значительных боевых сил». ${ }^{23}$ Поэтому, чтобы не «нарушать» это соглашение, и таким образом, потенциально эскалировать напряженность в отношениях с Россией, НАТО намеревается сохранять эти силы в ротационном формате, избегая вызывающий противоречия ярлык «постоянные». Столтен-

20 "Speech by NATO Secretary General Jens Stoltenberg at the Munich Security Conference," February 13, 2016, по состоянию на 9 марта 2016, http://nato.int/cps/en/ natohq/opinions_128047.htm.

21 Alberto Perez Vadillo, "From Munich to Warsaw: NATO rethinks deterrence," British American Security Information Council, February 22, 2016, по состоянию на 9 марта 2016, http://www.basicint.org/blogs/alberto-perez-vadillo-eu-non-proliferationconsortium-researcher/02/2016/munich-warsaw-nato.

22 “NATO's Readiness Action Plan. Fact Sheet," December 2014, по состоянию на 9 марта 2016, www.nato.int/nato_static_fl2014/assets/pdf/pdf_2014_12/20141202_ 141202-facstsheet-rap-en.pdf.

23 При положении, что Москва будет ограничивать развертывание своих конвенциональных сил - смотри Vadillo, "From Munich to Warsaw." 
берг подчеркнул важность реализации ПДПБ в феврале 2016 на встрече министров обороны НАТО в Брюсселе, заявив:

Мы увеличили присутствие НАТО в восточной части Альянса, расширив воздушное патрулирование, морское патрулирование и интенсивные учения. Мы согласовали меры по гарантированию для Турции - с батареями «Пейтриот», разведывательными самолетами АВАКС и усиленным морским присутствием в Восточном Средиземноморье и в Черном море. Мы утроили численность Сил реагирования НАТО до 40 000, с новой Объединенной оперативной группой повышенной готовности «Spearhead» («Наконечник копья») в их основе. ${ }^{24}$

Реальное выполнение ПДПБ и других конвенциональных обязательств, без сомнения, будет одной из важных тем в повестке дня предстоящего саммита в Варшаве.

С чисто американской точки зрения, Президент Барак Обама в июне 2014 анонсировал Инициативу по поддержке безопасности европейских стран (ИПБ). Первоначально Вашингтон имел намерение, чтобы это был «чрезвычайный ответ на российскую агрессию» на один год, на один миллиард долларов. ${ }^{25}$ Однако, в бюджете на 2017 финансовый год предложено увеличение в четыре раза финансирования от \$789 миллионов за 2016 год до \$3.4 миллиардов за 2017. ${ }^{26}$ Такое финансирование является шагом в правильном направлении. Оно не только помогает сдерживанию противников, но повышает и уверенность союзников. И если эти существенные улучшения на конвенциональном уровне, несомненно, являются посланием, почему бы не усилить это послание в ядерном измерении?

\section{Ядерные средства}

Несмотря на заявления НАТО о самотрансформации, похоже, что оно пренебрегает одной из основных опор своей коллективной безопасности. Другими словами, несмотря на продолжающееся ядерное потрясание саблями со стороны России, НАТО не анонсировало никаких изменений в своей политике ядерного сдерживания - союзники продолжали молчать. Это может быть преднамеренным, означать, что НАТО не нужно переходить ядерный порог, чтобы исполнить свои обязанности к союзникам в сценариях, которые не подразумевают полномасштабной войны. ${ }^{27}$ Однако, дальнейший анализ ядерной политики НАТО выявляет необходимость в проведении реформ на ядерной арене.

24 "NATO boosts its defence and deterrence posture," February 10, 2016, по состоянию на 9 марта 2016, www.nato.int/cps/en/natohq/news_127834.htm.

25 Mark F. Cancian and Lisa Sawyer Samp, "The European Reassurance Initiative," Center for Strategic and International Studies, February 9, 2016, по состоянию на 30 марта 2016, https://csis.org/publication/european-reassurance-initiative.

26 Там же.

27 Schuyler Foerster (Brent Scowcroft Professor of National Security Studies, Eisenhower Center for Space and Defense Studies), интервью с автором, 2 мая 2016. 
Отношение НАТО к ядерному сдерживанию не менялось многие годы. В техническом плане, силы ядерного сдерживания охватывают независимые стратегические силы трех ядерных сил Альянса: Соединенных Штатов, Соединенного Королевства и Франции - около 7800 ядерных зарядов в целом. $^{28}$ Эти «стратегические» силы включают традиционную ядерную триаду - бомбардировщики, межконтинентальные баллистические ракеты (МКБР) и подводные лодки. В любой момент эти три страны могут использовать свои стратегические ядерные силы самостоятельно, или предоставить их в расположение НАТО. Однако, доктрина НАТО полагает, что «высшая гарантия безопасности союзников обеспечивается стратегическими ядерными силами Альянса, в частности, силами Соединенных Штатов». 29

Согласно Ежегоднику Стокгольмского международного института исследований проблем мира (СМИИПМ) за 2015 год, в настоящее время ядерным оружием обладают девять стран. ${ }^{30}$ На первый взгляд, между странами НАТО и Россией, похоже, имеет место относительный общий баланс. Однако, союзники, как правило, не рассматривают стратегические силы США, Соединенного Королевства и Франции как «ядерное оружие НАTO». Это так, на первом месте из-за того, что Франция отказывается принимать участие в каком бы то ни было ядерном планировании в рамках НАТО, и во-вторых потому, что обмен ядерными ударами в стиле времен Холодной войны не является той угрозой, которая сильно беспокоит НАТО. Большинство экспертов обозначают это «НАТО-вское» оружие, вышеупомянутые авиационные бомбы В-61 как "тактическое» или нестратегическое ядерное оружие (НСЯО). Дисбаланс в плане «тактического» оружия в высшей степени благоприятствует России, причем отношение достигает приблизительно 6:1. ${ }^{31}$ Это ощутимое неравенство способностей легко исправить несколькими изменениями в боеготовности и политике по данному вопросу Альянса - рекомендации буду рассмотрены позже в этой работе.

Тогда как три ядерные силы НАТО и их политическое руководство всегда сохраняют собственность и полномочия над своим национальным

28 "Nuclear Force Reductions and Modernizations Continue; Peace Operations Increase," Stockholm International Peace Research Institute, June 15, 2015, по состоянию на 19 апреля 2016, www.sipri.org/media/pressreleases/2015/yb-june-2015.

29 Katarzyna Kubiak and Oliver Meier, “Updating NATO's nuclear posture: Necessary? Feasible? Desirable?" European Leadership Network, November 12, 2015, по состоянию на 19 апреля 2016, http://www.europeanleadershipnetwork.org/updatingnatos-nuclear-posture-necessary-feasible-desirable_3312.html.

30 "World nuclear forces," in SIPRI Yearbook 2015, Chapter 11, Stockholm International Peace Research Institute, по состоянию на 19 апреля 2016, https://www.sipri.org/ yearbook/2015/11.

31 Robert S. Norris and Hans M. Kristensen, "US tactical nuclear weapons in Europe, 2011," Bulletin of the Atomic Scientists 67, no. 1 (2011): 64-73, по состоянию на 5 января 2016, http://bos.sagepub.com/content/67/1/64.full. 
ядерным оружием, Альянс так же поддерживает уникальную способность, которую в целом можно охарактеризовать как "ядерное распределение». В основном, «Идея в том, что одним из решений проблемы 'зайцев' в обороне НАТО является то, чтобы союзники по НАТО несли некоторую долю финансового и политического бремени сохранения ядерного статуса Альянса путем предоставления своей территории для вынесенного вперед размещения ядерного оружия США», поясняет Джефри Льюис. ${ }^{32}$ Согласно этой договоренности, которая была достигнута до вступления в силу Договора о нераспространении от 1970 года, США хранят на территории пяти членов НАТО около 180 ядерных (тактических) авиационных бомб В-61. ${ }^{33}$

Эти «тактические» ядерные бомбы, созданные в 1960-х, считаются самым старым ядерным оружием в арсенале США и полностью финансируются налогоплательщиками США. ${ }^{34}$ США планируют модернизацию В-61 в рамках «Программы продления срока жизни» (ППСЖ) стоимостью в \$10 миллиардов, в результате выполнения которой четыре версии бомбы будут консолидированы в одну - вызывающую противоречия В-61 модификация 12. ${ }^{35}$ У «противоречивости» есть две стороны - в США противоречивость проистекает из факта, что предполагаемая стоимость программы взлетела от начальных \$4 миллиардов до реалистических на данный момент \$10 миллиардов. В международном плане, критики программы утверждают, что В-61 ППСЖ, с увеличенной точностью и уменьшенной мощностью, делает это оружие более используемым для военных планировщиков. $^{36}$ Это, в свою очередь, создает дестабилизирующий момент, связанный с данным оружием.

В соответствии с договоренностью о ядерном распределении, во время войны США передает ответственность за В-61 принимающему государству, которое затем использует свои СДН для сброса бомб на территорию врага. К несчастью, СДН «однако, быстро достигают конца своего срока службы, и являются единственным средством, через которое НАТО распределяет угрозу ядерного нападения на потенциальных противников во время кризиса между несколькими членами союза». ${ }^{37}$ Бельгия и Нидерланды в настоящее время используют F-16, а Германия и Италия - Торнадо.

32 Jeffrey Lewis, “A Steal at \$10 Billion," Foreign Policy, September 5, 2012, по состоянию на 30 марта 2016, http://foreignpolicy.com/2012/09/05/a-steal-at-10billion/.

${ }^{33}$ George Perkovich, Malcolm Chalmers, Steven Pifer, Paul Schulte, and Jaclyn Tandler, Looking Beyond The Chicago Summit: Nuclear Weapons in Europe and the Future of NATO (Washington DC: Carnegie Endowment for International Peace, 2012).

34 "B61 Bombs in Europe and the US Life Extension Program," British American Security Information Council, March 2016, по состоянию на 30 марта 2016, www.basicint.org/sites/default/files/BASIC_B61_briefing_Mar2016.pdf.

35 Lewis, "A Steal at \$10 Billion."

36 "B61 Bombs in Europe and the US Life Extension Program."

37 Edmond E. Seay, Countdown to Chaos? Timelines and Implications of Procurement Decisions for NATO's Dual-Capable Aircraft (Hamburg: British American Security In- 
Логика данной договоренности проста. Союзники разделяют политическое и тактическое «бремя» действительного использования ядерного оружия против врага. Даже союзники, которые не участвуют напрямую в миссиях по нанесению ударов СДН, регулярно делают свой вклад, участвуя в ядерных консультациях в рамках Группы ядерного планирования (ГЯП). Во время войны эти союзники дают свой голос за или против использования ядерного удара. Другие члены, например, Польша с ее самолетами F16, содействует ядерной миссии тем, что HATO называет SNOWCAT ролью. Эти союзники предоставляют неядерные способности, например, для подавления противовоздушной обороны противника (ППВОП). ${ }^{38}$ SNOWCAT может быть все - от командования и управления ядерными силами до обеспечения безопасности ядерного оружия на земле. Попросту говоря, пилоты Германии, Дании, Бельгии и Италии подвешивают на свои самолеты американские ядерные бомбы (хранимые на европейской территории) и сбрасывают их на врага, если поставлена такая задача. Хотя в теории данная концепция выглядит просто, она не лишена противоречий, проявившихся в последнем десятилетии.

\section{Второй фактор: доверие}

\section{Недавние ядерные дебаты}

Доверие является вторым фактором сдерживания, часто определяемым как мера политической воли для использования наличных военных способностей. Чтобы понять, в каком состоянии находится НАТО в смысле доверия к его политике ядерного сдерживания, важно рассмотреть, в каком состоянии оно находилось в недавнем прошлом. НАТО не чужды дебаты по ядерным вопросам. Есть очевидная польза от откровенных внутренних дискуссий по спорным для Альянса вопросам. Публичные дебаты в рамках НАТО, однако, могут иметь отрицательное влияние на доверие к Альянсу. Это особенно верно, если эти споры сеют зерна сомнения в умах противника. Тогда как новые члены НАТО, в целом, ценят высокое ядерное статус-кво, многие западные страны в последнее время предпочли бы, чтобы значение ядерного оружия существенно уменьшилось. ${ }^{39}$ В 2014 году доктор Роберт Цзулда объяснил подоплеку мышления одного из сторонников данной позиции, Германии:

Наиболее активным политическим адвокатом полного вывода является Германия, которая могла быть первой жертвой тактического ядерного оружия в период Холодной войны, так же как Польша. Согласно одному анализу НАТО от 1950-х (учения Carte Blanche 1955 и Lion Noire 1957), в

formation Council (BASIC), 2013), по состоянию на 19 января 2016, www.basicint.org/sites/default/files/nuclear_policy_paper_no_14_final.pdf.

39 Robert Czulda, "NATO Tactical Nuclear Weapons in Europe - Towards Modernisation or Withdrawal?" Baltic Security and Defence Review 17, no. 2 (2014): 80-111. 
случае агрессии против Западной Европы со стороны Варшавского договора, даже ограниченное использование ядерного оружия сделает территорию Германии необитаемой в результате взрывов и радиации. Этот страх и пацифистское движение, которое разрасталось с 1970-х, сделали немцев самими большими противниками ядерного оружия в Европе. $^{40}$

«Пацифистское» движение всплыло на поверхность снова в 2009, когда Германия возглавила призывы вывести ядерное оружие США из Европы. Ссылаясь на пражскую речь Обамы от 2009 года, министр иностранных дел Германии призвал «освободить Германию от ядерного оружия» и дополнил:

Мы ловим Президента Обаму на слово и начинаем разговоры с нашими союзниками с желанием, чтобы последние ядерные заряды, все еще размещенные в Германии, реликты Холодной войны, можно было бы в конце концов убрать. ${ }^{41}$

В интересах правды надо отметить, что таких взглядов придерживалась только одна из младших фракций в правительстве Германии, не вся страна в целом. Хотя общественность Германии настроена, в основном, против ядерного оружия, правительство, в общем и целом, понимает важность ядерного распределения в рамках Альянса. ${ }^{42}$ Тем не менее, Бельгия, Норвегия, Люксембург и Нидерланды поддержали внесение дерзкой инициативы Берлина в повестку саммита НАТО в Лиссабоне в 2010. Однако, государственный секретарь США в то время, Хиллари Клинтон, на встрече министров иностранных дел в Таллине, Эстония, в апреле 2010 (до саммита в Лиссабоне), выдвинула ключевой принцип политики - а именно, тактическое ядерное оружие США остается в Европе, избегая «оцепенение» всего Альянса. ${ }^{43}$ Позже, в 2010 году, НАТО опубликовало свою «Стратегическую концепцию», которая уточняет, что сдерживание, осуществляемое НАТО, будет основано на подходящем сочетании ядерных и конвенциональных способностей. ${ }^{44}$

Альянс продолжил эту линию, выпустив ОССО в 2012 году. ОССО, представленный на саммите в Чикаго, не рекомендует каких-либо изменений в политике НАТО по ядерному сдерживанию. Вместо этого, он просто наво-

40 Там же.

41 Sonia Phalnikar, "New German government to seek removal of US nuclear weapons," Deutsche Welle, October 25, 2009, по состоянию на 19 января 2016, www.dw.com/ en/new-german-government-to-seek-removal-of-us-nuclear-weapons/a-4824174.

42 Dr. Jeffrey Larsen (Director, Research Division, NATO Defense College, Rome, Italy), электронное письмо автору, 24 февраля 2016.

43 Damon V. Coletta, "Deterrence Logic and NATO's Nuclear Posture," Strategic Studies Quarterly 7 (Spring 2013): 69-92.

44 NATO, “Active Engagement, Modern Defence," November 19, 2010, по состоянию на 12 мая 2016, http://www.nato.int/cps/en/natolive/official_texts_68580.htm. 
дит лоск на «конфликтующие ядерные интересы в НАTO», ${ }^{45}$ декларируя, что «ядерное оружие является основным компонентом общих способностей НАТО для сдерживания и обороны», и что «текущая ядерная политика Альянса удовлетворяет требованиям эффективного сдерживания и обороны». ${ }^{46}$ Кроме принятия этих публичных документов, однако, члены НАТО часто избегают публичного обсуждения ядерного оружия, хотя внутренние споры по этому вопросу продолжают разгораться. ${ }^{47}$ Это беспокоит в свете того, что в последнее время Москва начинает потрясать своей ядерной саблей.

\section{Текущая ядерная политика НАТО}

Ядерная политика, определяемая главами государств, играет основную роль в формировании доверия к НАТО и создании политической воли. Действительно, Михаэль Рюле, руководитель отдела по энергетической безопасности международной администрации НАТО, утверждает, что «Ядерная политика всегда важнее текущего состояния ядерного сдерживания. Она демонстрирует солидарность двадцати восьми членов на уровне глав государств. Ничто другое не выглядит столь могущественным в глазах противника». ${ }^{48}$ В историческом плане, с момента создания Альянса в 1949 году саммиты НАТО давали главам стран-членов основную возможность оценить и определить стратегические направления деятельности Альянса. Такие встречи в верхах не являются регулярными, но они очень важная часть процесса принятия решений в Альянсе. К примеру, НАТО использует саммиты для инициирования новой политики, для приглашения новых членов и даже для демонстрации скоординированной реакции на конкретные действия оппонентов. С момента основания НАТО были проведены всего 26 саммитов. ${ }^{49}$ По традиции заявление, сделанное в конце каждого саммита, извещает о существенных изменениях или ожидаемых сообщениях. Естественно, любые изменения в ядерной позиции Альянса находят место в этих декларациях. К примеру, на Лиссабонском саммите в 2010 году была опубликована новая Стратегическая концепция (которая обычно служит дорожной картой сроком на 10 лет) и был постав-

45 Kamp, "NATO Summit in Warsaw."

46 NATO, "Deterrence and Defence Posture Review," May 20, 2012, по состоянию на 12 мая 2016, www.nato.int/cps/en/SID-4E5D5633-EACD44C0/natolive/official_ texts_87597.htm.

47 Rachel Staley Grant, "Rethinking nuclear deterrence and burden-sharing," British American Security Information Council (BASIC), July 22, 2013, по состоянию на 19 января 2016, http://www.basicint.org/news/2013/rethinking-nuclear-deterrence-andburden-sharing.

48 Michael Rühle, "The Broader Context of NATO's Nuclear Policy and Posture," Working Paper No. 89 (Rome: NATO Defense College, January 2013).

49 NATO, "Summit Meetings," November 6, 2015, по состоянию на 5 января 2016, http://www.nato.int/cps/en/natolive/topics_50115.htm. 
лен вопрос о создании ОССО. Эти два документа являются основой ядерной политики НАТО. В число ключевых положений, содержащихся в этих документах, входят:

- «Фундаментальной целью ядерных сил НАТО является сдерживание».

- «Сдерживание, основанное на соответствующем сочетании ядерных и конвенциональных способностей, остается основным элементом целостной стратегии НАТО».

- «Ядерное оружие является основным компонентом целостных способностей Альянса, предназначенных для сдерживания и обороны, наряду с конвенциональными силами и силами противоракетной обороны».

- «НАТО остается приверженным к контролю над вооружениями, разоружению и нераспространению, но пока существует ядерное оружие, оно останется ядерным альянсом».

- «Группа ядерного планирования является форумом для консультаций в рамках НАТО по ядерному сдерживанию». 50

22 мая 2015 года Столтенберг объявил, что следующая встреча в верхах состоится 8 июля 2016 года в Варшаве. В этом контексте он заявил: «Мы уже осуществляем самое большое укрепление нашей коллективной обороноспособности с конца Холодной войны. В Варшаве мы проложим курс для адаптации Альянса к новой среде безопасности таким образом, чтобы НАТО имело готовность защищать всех своих членов от угроз с любого направления». ${ }^{51}$ Тогда как фокус подготовки к встрече в Варшаве в основном лежал на ПДПБ и учении «Trident Juncture», как усовершенствование конвенциональных сил Альянса, так и публичные дискуссии по ядерным инициативам НАТО остались неизвестными широкой общественности.

Концепция, что у Альянса нет врагов, является одним из положений текущей политики, которое ослабляет доверие к политике сдерживания Альянса. Оно противоречит традиционной логике сдерживания. Чтобы осуществлять сдерживание врага, нужно сначала определить, кто есть противник. Политически удобное положение, что «у НАТО нет врагов», никого не сдерживает. НАТО должно определить что и кто точно является наибольшей угрозой для Альянса. Есть ли необходимость осуществлять сдерживание не только таких государственных акторов, как Россия, Северная Корея, Пакистан и Китай, но таких негосударственных акторов, как ИГ? Сделав это, НАТО затем сможет определить соответствующие требования

50 NATO, "NATO's Nuclear Deterrence Policy and Forces," December 3, 2015, по состоянию на 5 января 2016, www.nato.int/cps/en/natohq/topics_50068.htm.

51 NATO, "NATO Secretary General announces dates for 2016 Warsaw Summit," May 22, 2015, http://www.nato.int/cps/en/natohq/news_120085.htm. 
в смысле сил, политики и бюджета для нейтрализации этих угроз со стороны конкретных противников. Варшава с ее уникальным географическим положением дает идеальную возможность осуществить необходимые реформы для повышения доверия к ядерному сдерживанию, осуществляемому НАТО.

\section{Третий фактор: коммуникация}

Преодоление разрыва в стратегической коммуникации

Последним фактором является коммуникация. Чтобы НАТО осуществляло успешное сдерживание данного противника, оно должно коммуницировать свои способности и свою надежность способом, который противник понимает. Без этого первые два фактора, возможно, не имеют значения. $\mathrm{K}$ примеру, Россия, и конкретно Путин, последовательно демонстрировали, что они понимают и уважают только силу. Хотя дипломатия должна быть первым портом захода, НАТО всегда должно начинать дипломатические переговоры с позиции силы. Столтенберг подчеркнул это в январе 2016, сказав: «Нет никакого противоречия между увеличением мощи НАТО и взаимодействием с Россией. На деле, только если мы будем сильными, мы сможем развить конструктивные отношения сотрудничества». ${ }^{52}$

Чтобы достичь этого, НАТО должно улучшить свою стратегическую коммуникацию. Конкретнее, оно должно изменить свое мышление по ядерному вопросу и «должно не рассматривать обсуждение ядерного развития, как нечто выходящее за пределы допустимого из-за его противоречивого характера». 53 Это не новая идея. Действительно, до саммита в Чикаго в 2012, члены фонда Карнеги за международный мир писали: «Чтобы избежать каскадной потери доверия, после саммита в Чикаго лидеры НАТО должны подготовить Альянс к принятию некоторых фундаментальных решений, касающихся его политики сдерживания и обороны». ${ }^{54}$ Если это не будет сделано, как поясняет Джордж Перкович, «оно начнет терять способность принимать коллективные решения по ядерным способностям и ядерной политике НАТО». ${ }^{55}$ Только в таком случае Альянс избегнет неминуемого «разоружения по умолчанию» в результате не учета необходимости модернизации на ядерной арене. ${ }^{56}$ Примером такого «разоружения по умолчанию» является нежелание Германии заменить самолеты Торнадо для выполнения миссии нанесения ядерного удара. Хотя Германия согла-

52 The Secretary General's Annual Report 2015 (Brussels: NATO Public Diplomacy Division, 2016), по состоянию на 12 мая 2016, http://www.nato.int/nato_static_fl2014/ assets/pdf/pdf_2016_01/20160128_SG_AnnualReport_2015_en.pdf\#page=27.

53 Rühle, "The Broader Context of NATO's Nuclear Policy and Posture."

54 Perkovich et al., Looking Beyond The Chicago Summit.

55 Там же.

56 Steven Pifer, "NATO, Nuclear Weapons and Arms Control," Arms Control Series, Report 7 (Brookings, July 2011), по состоянию на 20 января 2016, www.brookings.edu/wp-content/uploads/2016/06/0719_arms_control_pifer.pdf. 
силась на продление жизни Торнадо, она рискует полностью потерять способность выполнять миссию нанесения ядерного удара, если в ближайшее время не примет решения по замещению Торнадо. Это, однако, потребует проведения публичного обсуждения финансирования приобретения самолета, способного нести ядерное оружие - тема, которую политические лидеры стараются избегать. Германия идентифицировала нехватку способности СДН еще десять лет назад, но все еще затягивает идентификацию заменителя. Это уже само по себе является коммуницированием противнику намерений, которые подрывают целостный эффект сдерживания.

Продолжающееся молчание НАТО на ядерном фронте может оказаться тревожным для тех союзников и партнеров, которые пытаются получить гарантии против политики России в последнее время. Денис Хили, британский министр обороны в конце 1960-х, однажды сказал: «Достаточно пяти процентов доверия к способности американцев нанести ответный удар, чтобы сдержать русских, и девяносто пять процентов для успокоения европейцев». ${ }^{57}$ После почти пятидесяти лет "теория сдерживания» Хили все еще звучит достоверно в момент, когда НАТО пытается найти баланс между сдерживанием и заверениями. К примеру, в Основополагающем акте НАТО-Россия 1997 года перечислены три «не», и НАТО заявляет, что «не имеет намерения, не имеет плана и не имеет причин для размещения ядерного оружия на территории новых стран-членов». ${ }^{58}$ Это заявление предназначено для заверения Москвы, что расширение с шестнадцати до двадцати восьми членов не является угрозой для России. Однако, Мэтью Карничниг в своей статье от 2014 года заявляет, что «Балтийские члены НАТО и Польша утверждают, что Россия очевидно нарушила этот акт, и что Альянс больше не обязан соблюдать его». ${ }^{59}$ Далее, Джон Корнблюм, бывший помощник по европейским делам государственного секретаря США, который участвовал в подготовке проекта акта и в переговорах по нему, объясняет редко обсуждаемый нюанс данного соглашения: «В нем сказано, что если условия изменяются, все договоренности отпадают. Есть множество клауз, позволяющих выйти из договора, если противная сторона не соблюдает свои обязательства. Очевидно, русские нарушили практически все свои обязательства. Никоим образом нельзя утверждать, что условия также гармоничны, как когда соглашение было подписано». ${ }^{60}$ Расширение охвата миссии нанесения ядерного удара с включением стран Центральной и Восточной Европы, например, способствовало бы повыше-

57 Denis Healey, The Time of My Life (London: Michael Joseph, 1989), 243.

58 Luis Simón, "NATO," in Tactical Nuclear Weapons and Euro-Atlantic Security: The Future of NATO, ed. Paolo Foradori (New York: Routledge, 2013), 107-124.

59 Matthew Karnitschnig, "Pact With Russia Keeps NATO Bases at a Distance, But Should It?" Wall Street Journal, September 3, 2014, по состоянию на 29 февраля 2016, http://blogs.wsj.com/brussels/2014/09/03/qa-1997s-nato-russia-founding60 act/tab/print/.

Там же. 
нию уверенности союзников на востоке, и в то же время не было бы нарушением Акта о создании.

Новые члены НАТО, в особенности многие из стран ЦВЕ, рассматривают присутствие американских В-61 в Европе как символическую связь с США. Эта связь на первом месте, без сомнения, привлекла недавних членов к вступлению в Альянс. В публично доступных источниках утверждается, что имеется приблизительно 150-200 американских бомб В-61, размещенных в Германии, Бельгии, Нидерландах, Италии и Турции. ${ }^{61}$ Для ЦВЕ стран, это оружие служит ежедневным напоминанием, что трансатлантическое партнерство все еще живо и находится в добром здравии. Это партнерство является критически важным для доверия к политике «нападение на одного, это нападение на всех», или Статьи V Североатлантического договора. С точки зрения ЦВЕ, такие политические гарантии нельзя переоценить в период, когда администрация Обамы продолжает свои явные действия по «развороту» к Тихоокеанскому региону. Кроме того, страны ЦВЕ боятся, что российские инвазии в Украину и в Грузию в 2008 «могут не быть изолированными инцидентами, а симптомом более широких амбиций Москвы, направленных на восстановление российской сферы влияния на территории бывшего Советского Союза, и эти планы могут стать угрозой для региональной стабильности и напрямую для стран-членов НАТО». ${ }^{62}$ Улучшение стратегической коммуникации по ядерному вопросу улучшает восприятие политической воли и, таким образом, улучшает сдерживание.

\section{Разговор о деньгах}

Разумное расходование денег на оборону является еще одним средством, с помощью которого третий фактор можно использовать для коммуникации своих намерений и тем самым осуществлять сдерживание противников. Оно указывает на наличие политической воли и эффективно коммуницирует решимость и приоритеты. Столтенберг подчеркнул это в ежегодном докладе Генерального секретаря в 2016 году: «Есть много способов, с помощью которых союзники демонстрируют свою солидарность, и один из них - это инвестиции в оборону». ${ }^{63}$ К сожалению, отсутствие расходов на оборону также передает послание противнику. Бывший министр обороны США, Роберт Гейтс, забил тревогу для Европы в 2011, заявив: «Голая действительность состоит в том, что у Конгресса США - и у американской политической верхушки - все меньше желания и терпения расходовать все более ценные финансы в интересах стран, которые очевидно не желают выделять необходимые ресурсы или делать необходимые изменения, чтобы быть серьезными и работоспособными

61 Norris and Kristensen, "US tactical nuclear weapons in Europe, 2011."

62 Matthew Kroenig, "Facing Reality: Getting NATO Ready for a New Cold War," Survival: Global Politics and Strategy 57, no. 1 (February-March 2015): 49-70.

63 The Secretary General's Annual Report 2015. 
партнерами в деле своей собственной обороны». ${ }^{64}$ Это заявление, в сочетании с такими инициативами, как предложение Германии убрать американские В-61 из Европы, продолжает подрывать уверенность в настоящей сплоченности Альянса. Даже наиболее вероятный претендент на номинацию республиканцев на пост президента, Дональд Трамп, сделал предупредительный выстрел перед носом натовского корабля на собрании в Висконсине в мае 2016, сказав, что Союзники «не платят свою справедливую долю», и что «они будут платить, в том числе за прошлые недостачи, или им придется сойти. И если это развалит НАТО, то так тому и быть». ${ }^{65}$ Такие комментарии со стороны Трампа, несмотря на конкретный контекст, только подбрасывают дрова в огонь российских попыток нагреть руки на разделении Альянса.

НАТО поставило перед своими членами задачу расходовать не менее $2 \%$ своего валового внутреннего продукта (ВВП) на оборону, и чтобы по крайней мере $20 \%$ из расходов на оборону шли на приобретение основного оборудования, в том числе на исследования и разработки. ${ }^{66}$ Поскольку очень немногие члены удовлетворяют этому требованию, в заключительной декларации саммита в Уэльсе в 2014 году это обязательство было смягчено путем согласия, что те из членов, которые не соответствуют требованию о расходе 2 \% должны, как минимум:

- Прекратить любое уменьшение расходов на оборону;

- Стремиться увеличивать расходы на оборону в абсолютном выражении по меру роста ВВП;

- Стремиться к достижению $2 \%$ отметки в рамках десяти лет. ${ }^{67}$

В докладе от 2016 года, спустя почти восемнадцать месяцев после декларации, Столтенберг привел информацию о том, как каждая из стран НАТО движется к этой цели. В докладе он сказал:

Что касается одновременно $2 \%$ и 20\%, только три [из 28] страны НАТО удовлетворяют правилам, с которыми согласились все члены НАТО. Несмотря на тот факт, что в 2015 году многие страны НАТО увеличили свои военные расходы, их сокращение в некоторых странах с развитыми экономиками означает, что в целом оборонные расходы НАТО в 2015 году уменьшились. ${ }^{68}$

64 Robert Burns, "Gates blasts NATO, questions future of alliance," Associated Press, June 10, 2011, http://www.salon.com/2011/06/10/eu_gates_nato_doomed/.

65 "Trump Fine With 'Breakup' of NATO," Newsmax, May 2, 2016, по состоянию на 2 мая 2016, www.newsmax.com/Headline/trump-nato-break-up/2016/04/02/id/ 722004/.

66 NATO, Wales Summit Declaration.

67 Там же.

68 The Secretary General's Annual Report 2015. 
В этом и заключается проблема. Почему многим американским лидерам не нравится финансовый дисбаланс в Альянсе? И снова Столтенберг разъясняет: «В 2015 году США давали 50\% от валового внутреннего продукта (ВВП) Альянса и несли $72 \%$ от всех оборонных расходов НАТО». ${ }^{69}$ Как много раз в течение своей политической карьеры, вице-президент США, Джо Байден, говорил: «Не говорите мне, каковы ваши ценности. Покажите мне ваш бюджет, и я скажу, что вы цените». ${ }^{70}$ Честно говоря, США всегда несли непропорционально высокую долю в оборонных инвестициях НАТО. Однако, после окончания Холодной войны, эта непропорциональность существенно увеличилась. ${ }^{71}$

Хотя многие из стран НАТО утверждают, что «результат» страны более важен, чем такой объективный показатель, как процент ВВП, но НАТО выбрало именно ВВП в качестве мерила. Возможно более информативными с точки зрения противника являются тенденции в оборонных расходах в конкретных странах, особенно в тех странах НАТО, которые «едины» и вновь подтвердили $2 \%$ критерий после саммита в Уэльсе в 2014 году. В работе, опубликованной в Defense One в 2015, Кедар Павги приводит процентное изменение оборонных расходов после украинского кризиса в 2014 и уэльского обещания. А именно, Павги показывает, что самые восточные страны в НАТО демонстрируют наибольшее увеличение оборонных расходов после незаконной аннексии Крыма и оккупации Восточной Украины Россией. ${ }^{72}$ Обнадеживающим признаком является то, что страны принимают угрозы всерьез и пытаются соответственно корригировать свои оборонные расходы. К сожалению, такие страны, как Украина и Грузия, недавно поняли, что профессиональные вооруженные силы невозможно создать за один день. Последние доклады дают основание полагать, что тенденция изменяется к лучшему. По мнению Марка Чемпион, «Члены НАТО наконец решили переломить тенденцию уменьшения оборонных расходов. США платят $22 \%$ из приблизительно \$2.3 миллиардов общего бюджета (оправданная доля, учитывая, что на США приходится $50 \%$ от общего для Альянса ВВП). Они продолжают обеспечивать слишком большую часть от действительных расходов, но роспуск альянса имеет смысл, только если США могут отказаться от своих европейских обязательств. Они не могут». ${ }^{73}$ Продолжение обращения внимания на соответствующие

69 Там же.

70 “Biden's Remarks on McCain's Policies," New York Times, September 15, 2008, по состоянию на 2 мая 2016, www.nytimes.com/2008/09/15/us/politics/15textbiden.html.

71 The Secretary General's Annual Report 2015.

72 Kedar Pavgi, "NATO Member's Defense Spending, in Two Charts," Defense One, June 22, 2015, по состоянию на 29 апреля 2016, www.defenseone.com/politics/ 2015/06/nato-members-defense-spending-two-charts/116008/.

73 Marc Champion, "Trump Asks a Good Question About NATO (and Botches It)," Bloomberg View, April 5, 2016, по состоянию на 29 апреля 2016, 
уровни оборонных расходов говорит противникам о многом, так как они видят усовершенствование способностей, которое указывает на наличие политической воли. Польша, как союзник, который «подтверждает деньгами свои слова», является отличным местом не только для продолжения текущих реформ, но и для расширения этих реформ и на ядерную сферу.

\section{Рекомендации}

Работы таких теоретиков традиционного ядерного сдерживания, как Броди, ${ }^{74}$ Снайдер ${ }^{75}$ и Шеллинг ${ }^{76}$ остаются актуальными для НАТО в двадцать первом веке, хотя каждый из них придерживается к несколько отличной от других точки зрения. НАТО комбинирует и упрощает разные подходы этих теоретиков сдерживания, продолжая использовать «Три фактора» как средство для оценки сдерживания. Использование чего-то другого для объяснения, почему сдерживание действительно работает, остается почти невозможным. Однако, учитывая упомянутые недостатки в этих трех опорах, ниже приведены шесть изменений, которые НАТО следует рассмотреть в Варшаве при определении своей политики сдерживания.

\section{\# 1: Добавление СДН и миссии нанесения удара для Польши и Турции}

В одном исследовании корпорации РЭНД от 2016 года публично идентифицированы очевидные слабости способностей НАТО в Балтийском регионе: «При нынешнем состоянии НАТО не может успешно защищать территорию своих подвергающихся наибольшей опасности членов». 77 "Результат для НАТО был катастрофическим», говорится в докладе. «При проведении множества симуляций российские силы устраняли или обходили все очаги сопротивления и оказывались у ворот Риги или Таллина, или у ворот и той, и другой столицы где-то в промежутке от 36 до 60 часов после начала вооруженных действий». ${ }^{78}$ Подтягивание ядерного потенциала региона могло бы быстро закрыть этот разрыв. Такой шаг не будет первым в истории НАТО. Действительно, США разместили ядерное оружие в Ев-

www.bloombergview.com/articles/2016-04-05/trump-asks-right-question-botchesanswer-on-nato.

74

Bernard Brodie, ed., The Absolute Weapon: Atomic Power and World Order (New York: Harcourt, Brace and Company, 1946); Bernard Brodie, Strategy in the Missile Age (Princeton, NJ: Princeton University Press, 1959).

75 Glenn Snyder, Deterrence and Defense: Toward a Theory of National Security (Princeton: Princeton University Press, 1961).

76 Thomas Schelling, The Strategy of Conflict (Cambridge: Harvard University Press, 1960); Thomas Schelling, Arms and Influence (New Haven, CT: Yale University Press, 1966).

77 Vandiver, "Russia Defeats NATO in Baltic War Game."

78 Там же. 
ропе на первом месте из-за более слабых по сравнению с СССР конвенциональных вооруженных сил.

Добавление миссии НАТО нанесения ядерного удара польским F-16 одновременно повысить уверенность союзников на восточном фланге и окажет сдерживающее воздействие на Россию, продемонстрировав силу и солидарность Альянса. Поскольку НАТО не будет перемещать какое-либо вооружение или создавать в Польше объекты для хранения ядерных зарядов, это не будет нарушение Основополагающего акта НАТО-Россия от 1997 года. На основании двустороннего договора между США и Польшей Альянс уже использует авиабазу Ласк как основную базу для размещения летательных аппаратов НАТО в Польше на временной ротационной основе. Кроме того, польские F-16 уже принимают участие в ежегодных учениях HATO «Steadfast noon - STRIKEVAL» в неядерной роли. ${ }^{79}$ Польские самолеты просто надо будет приспособить для несения ядерного оружия, и после минимальной подготовки они будут приведены в состояние оперативной готовности.

Критики тактического ядерного оружия НАТО часто указывают на нереалистичность способности СДН покрыть расстояние, требуемое для сценария действительного ядерного удара. Во-первых, пересечение больших расстояний от западноевропейских баз до места боевых действий, которые насыщены системами предотвращение доступа и проникновения в воздушное пространство (ПДПВП), выглядит не просто нереалистичным, а прямо самоубийственным. Однако, воздушная база Ласк в Польше является решением для этой геометрической задачи. Она расположена в 178 милях от белорусской границы и в 201 миле от российской границы в Калининградской области. Ханс Кристенсен описывает это так: «При скорости в 1800 километров в час (1100 миль в час или числе Маха 1,47) F-16, вылетевший из базы Ласк, сможет достичь Калининграда за 12 минут и Москвы менее чем за час. ${ }^{80}$

Насколько реалистична такая рекомендация с политической точки зрения, может быть спорным. В декабре 2015 года новое польское правительство подняло брови в удивлении, когда заместитель министра обороны, Томаш Шатковски, сказал Полсат ньюз 2, что Польша предпринимает «конкретные шаги» для участия в ядерном распределении в НАТО. ${ }^{81}$ С другой стороны, польский министр обороны немедленно это опроверг, сказав, что «Польша не принимает участия в какой-либо работе по присоединению к программе НАТО по ядерному распределению». ${ }^{82}$ Из всего этого можно сделать логический вывод, что заявление Шатковского указывает

79 Kristensen, "Polish F-16s in NATO Nuclear Exercise in Italy."

80 Vandiver, "Russia Defeats NATO in Baltic War Game."

81 Hans M. Kristensen, “Adjusting NATO's Nuclear Posture," Federation of American Scientists, December 7, 2015, по состоянию на 23 марта 2016, http://fas.org/blogs/ security/2015/12/poland/.

82 Там же. 
на углубление дискуссий в рамках Альянса. С другой стороны, возможно, это представляет собой просто выражение политического интереса конкретного чиновника в новом правительстве. Как бы там ни было, последующее опровержение с польской стороны говорит о многом в смысле продолжающейся секретности всего, что связано с ядерной тематикой в НАТО. Как сказал один из чиновников в НАТО газете Гардиан в 2015 году: «Мы не можем вдаваться в подробности наших ядерных дискуссий. Это внутренние, чувствительные и секретные вопросы. Единственное, что я могу сказать, это то, что НАТО непрерывно оценивает все аспекты военной деятельности России, в том числе и ядерную риторику России». ${ }^{83}$

Возвращение Турции к выполнению миссии ядерного удара, готовностью к выполнению, которой турецкие военно-воздушные силы раньше располагали, окажется гораздо проще, и для достижения снова оперативной готовности потребуется приблизительно год. ${ }^{84}$ Учитывая последние действия России в Сирии, поддерживать ядерные способности в юго-восточной части Альянса имеет смысл. Большинство экспертов единодушны в том, что полномасштабная ядерная война не является их ночным кошмаром. Им скорее являются региональные конфликты, эскалирующие между ядерными силами и возникшие по случайности или по ошибке. Сбитие российского истребителя Турцией в ноябре 2015 года после нарушения воздушного пространства, продлившегося семнадцать секунд, заснятое на видео, ярко иллюстрирует, как может развиваться такой сценарий. Учитывая выраженную Россией готовность использовать ядерное оружие как средство для "де-эскалации», поддерживание способности к нанесению ядерного удара в этом регионе было бы предусмотрительно. Если Россия будет знать, что ядерный вариант в этой области имеет место для НАТО, это может оказать сдерживающее воздействие на такие «де-эскалирующие» ядерные варианты. Размещение в Турции средств, обеспечивающих ядерную способность, также даст НАТО возможность, если это необходимо, в будущем противодействовать непредсказуемым действиям со стороны Ирана, Пакистана и Индии.

\section{\# 2: Интегрирование Транспортного крыла для перевозки тяжело- весных грузов С-17 в Основные воздушно-транспортные силы для перевозки ядерных зарядов}

Нахождение для новых членов творческих способов, с помощью которых они могли бы внести свой вклад в ядерную миссию, остается трудным делом. Россия интерпретирует большинство шагов в этом направлении как направленные на эскалацию по своему характеру. Добавление Способно-

83 Ewen MacAskill, "NATO to review nuclear weapon policy as attitude to Russia hardens," Guardian, June 24, 2015 по состоянию на 23 марта 2016, www.theguardian.com/world/2015/jun/24/nato-to-review-nuclear-weapon-policyas-attitude-to-russia-hardens.

84 Hans Kristensen, интервью автора, 1 апреля 2016. 
сти для стратегических воздушных перевозок (ССВП), в которой участвуют 12 государств, реализуемая многонациональным Транспортным крылом для перевозки тяжеловесных грузов (ТКПТГ) к Основным воздушно-транспортным силам для перевозки ядерных зарядов США даст Альянсу средство для быстрых воздушных перевозок размещенных в Европе тактических ядерных зарядов США с любого аэродрома на театр военных действий. Выполнение этой рекомендации сэкономило бы деньги как в стратегическом, так и в тактическом плане, и не было бы воспринято как направленное на эскалацию. Это также позволит НАТО решить вышеупомянутую геометрическую задачу, дав главнокомандующему союзными войсками в Европе возможность выполнять миссию нанесения ядерного удара с любого аэродрома, а не только с шести воздушных баз, на которых в настоящее время размещены В-61. НАТО могло бы быстро переносить В61 на борт С-17 и хранить их там в течении короткого срока - по существу используя самолеты как временное хранилище. Такая концепция рассеивания является ощутимым сигналом, который будет средством для сдерживания России и даст Альянсу дополнительные варианты эскалации без реальных самолетовылетов для нанесения ударов.

Расширением охвата способности для воздушных перевозок ядерных зарядов с включением двенадцати государств, участвующих в ССВП, Альянс так же создаст альтернативную неэскалационную форму ядерного распределения. Такое распределение одновременно обеспечит более широкое участие в ядерной миссии, успокоит страхи тех государств, которые воспринимаются как наиболее уязвимые от внешних угроз, и облегчит бремя США по финансированию воздушных перевозок ядерного оружия. В число этих двенадцати государств входят десять членов НАТО и два государства, участвующие в инициативе «Партнерство ради мира», которые в принципе не участвуют в ядерной политике НАТО. В число натовских участников входит Венгрия, являющаяся принимающим государством этой программы, а также Болгария, Эстония, Литва, Нидерланды, Норвегия, Румыния, Польша, Словения и США. Странами-партнерами по инициативе «Партнерство ради мира», уже участвующими в ССВП, являются Швеция и Финляндия. ${ }^{85}$ Многие из этих стран в настоящее время не принимают участие в ядерной политике НАТО, кроме как в качестве членов Группы ядерного планирования (ГЯП). Это позволит им дать свой вклад в очень конкретной форме. Что касается Швеции и Финляндии, это было бы не эскалирующим способом дать «оболочку» ядерной игре НАТО невиданным доселе методом.

85 "The Strategic Airlift Capability (SAC)," SAC website, по состоянию на 23 марта 2016, www.sacprogram.org/en/Pages/The\%20Strategic\%20Airlift\%20Capability.aspx. Транспортное крыло для перевозки тяжеловесных грузов в Венгрии с тремя самолетами C-17 дает способность осуществлять стратегические воздушные перевозки. 
Это вполне реалистический вариант. ТКПТГ достигло полной оперативной готовности (ПОГ) в 2012 году и уже имеет в своем составе бывших членов экипажей из $4^{-о и ̆ ~ э с к а д р и л ь и ~ д л я ~ в о з д у ш н ы х ~ п е р е в о з о к ~ В о е н н о-в о з-~}$ душных сил США, единственной эскадрильи для воздушных перевозок ядерного оружия Министерства обороны (МО). ${ }^{86}$ Концепция ССВП является прорывной инициативой в сфере умной обороны и общего использования способностей для обороны. Она дает схему эффективного по расходам общего использования способности и потенциала, которую НАТО могло бы применять и в других областях. Согласно ее вебсайту,

Программа Способности для стратегических воздушных перевозок, запущенная в сентябре 2008, является независимой и многонациональной программой, которая дает участвующим 12 странам критически важную боевую способность путем обладания и эксплуатации трех реактивных грузовых самолетов дальнего радиуса действий Boeing C-17 Globemaster III. ССВП базируется на воздушной базе Венгерских сил обороны (ВСО) Папа в западной Венгрии. ${ }^{87}$

По существу, эти двенадцать стран делят наличное полетное время трех самолетов, которые можно «использовать для миссий без предварительных консультаций с другими участниками в интересах их национальной обороны, НАТО, ЕС или ООН и для гуманитарных операций». ${ }^{88}$ Чтобы предложение о воздушных перевозках ядерного оружия стало бы реальностью, США, однако, придется «делиться» со своими союзниками и доверять им до не имеющей прецедента степени.

В настоящее время экипажи Основных сил для воздушных перевозок ядерных зарядов США поддерживают строгие стандарты подотчетности через Программу надежности персонала (ПНП). ПНП есть механизм МО, посредством которого оно гарантирует, что весь личный состав, который входит в контакт с ядерным оружием, находится в здравом состоянии ума и тела. Очевидно, чтобы расширить ПнП к союзникам по НАТО, необходимы административные изменения, подразумевающие серьезный анализ риска. Хотя ответственность и владение оружием, по всей видимости, останутся за прикомандированным американским членом экипажа, остальные позиции в экипаже, позиции пилота и ответственного за груз будут заполняться представителями других стран в ТКПТГ. В конце концов, какие более надежные «гарантии» могут дать Соединенные Штаты заинтересованным членам НАТО, чем позволить им иметь доступ и нести ответственность за транспортировку наиболее разрушительного оружия? Прецедент уже существует: чтобы выполнять свою миссию, Министерство энергетики и МО признают версии ПНП друг друга.

\footnotetext{
86 Blake Jones, интервью автора, 22 марта, 2016.

87 "The Strategic Airlift Capability (SAC)."

88 Там же.
} 
Не может быть лучшего времени, чем сейчас, чтобы начать подготовку, необходимую для включения членов экипажей С-17 ТКПТГ в бизнес воздушных перевозок ядерного оружия. В 2020 США начнут заменять нынешние ядерные бомбы В-61 в Европе новой версией В-61-12. ${ }^{89}$ Такие объемные воздушные перевозки почти 200 бомб В-61 в Европу и из Европы станут серьезным сдерживающим фактором сами по себе. Новая модель В61-12, воспринимаемая пацифистами как вызывающая серьезные противоречия благодаря новому сочетанию малой мощности и хвостового комплекта для наведения, наверняка будет лучше воспринята европейской общественностью, если замена будет осуществлена ССВП (а не США).

\section{\# 3: Поддержсивание статус-кво в плане мест размещения и количе- ства B-61}

Хотя переговоры по ядерному разоружению затихли в результате состояния нынешней среды безопасности, волна, несомненно, повернется, когда отношения с нынешними противниками изменятся. Оглядываясь на эпоху «Россия является стратегическим партнером» 2009 года, Альянс мудро принял коллективное решение не разоружаться. Сохраняя текущую политику размещения тактического ядерного оружия во всех пяти нынешних принимающих государствах, НАТО легко выигрывает политические и оперативные очки. Во-первых, Альянс сохраняет большое моральное преимущество (и потенциальное дипломатическое превосходство в будущем), соблюдая Основополагающий акт НАТО-Россия от 1997 года, поскольку он не размещает ядерное оружие на территории ни одного «нового» члена. Это может выглядеть тривиальным, но в момент, когда Россия нарушила территориальную целостность Украины, она также нарушила Будапештский меморандум от 1994 года, который содержал гарантии для безопасности Украины. 90 Избежать искушения одно нарушение оправдывать другим дает Альянсу, и США, рычаг для воздействия в будущих переговорах по вооружениям с Россией. Это может быть полезным, когда в конце концов НАТО обратит внимание на большую разницу в запасах тактического ядерного оружия между США и Россией. По оценкам Кристенсена и Роберта Норриса, Россия сохраняет три тысячи ядерных тактических зарядов, тогда как США поддерживают приблизительно пятьсот. ${ }^{91}$ Во-вторых, НАТО твердо поддерживает свой публичный нарратив о важности ядерного измерения Альянса. И последнее, это сохраняет участие западноевропейцев в игре. В период, когда имеются разногласия о ценности этих вооружений в Европе, это нельзя недооценивать. В докладе от 2006 года для Управле-

89 British American Security Information Council, "B61 Bombs in Europe and the US Life Extension Program."

90 Steven Pifer, "Mr. Lavrov, Russia, and the Budapest Memorandum," Brookings, January 28, 2016, по состоянию на 1 апреля 2016, www.brookings.edu/blogs/orderfrom-chaos/posts/2016/01/28-russia-lavrov-budapest-memorandum-pifer.

91 Norris and Kristensen, "US tactical nuclear weapons in Europe." 
ния НАТО по публичной дипломатии, доктор Джефри Ларсен описывает уникальные отношения между Соединенными Штатами и принимающими государствами:

По всей видимости, Соединенные Штаты держат свое ядерное оружие в Европе в основном потому, что они думают, что их европейские союзники хотят этого. Европейские государства с СДН, с другой стороны, остаются верными ядерной миссии прежде всего потому, что они думают, что США ожидают этого от них, но в миссии СДН они остаются сомневающимися партнерами. Нет консенсуса в Альянсе о необходимости ядерного оружия. Обе стороны не слушают друг друга - точнее, они не говорят друг с другом. Никто не хочет раскачивать лодку.

По общему признанию, цитата Ларсена несколько устарела. За последние десять лет среда безопасности драматически изменилась. Однако, одна вещь остается неизменной: Германия все еще не приняла решение о замене своих Торнадо, способных нести ядерное оружие. Вместо этого она откладывает дело в долгий ящик посредством программы продления срока жизни. Поэтому с уверенностью можно предположить, что хотя Германия доказала свою поддержку ядерной миссии на пассивном уровне, ей еще предстоит выделить требуемые ресурсы, чтобы убедить скептиков, что она относится серьезно к своей долгосрочной приверженности к миссии нанесения ядерного удара. Если Германии позволят «разоружиться по умолчанию», то и другие страны с СДН могут пойти тем же путем.

\section{\#4: Повышение ядерной боеготовности (уменьшение времени реакции) на базах СДН}

Согласно докладу СП за 2011 год, «хотя у НАТО нет действующих оперативных планов по использованию ядерного оружия, Соединенные Штаты и определенные члены НАТО предоставляют силы, и от них требуется поддерживать способность быть готовыми к проведению ядерных операций в рамках 30-дневного, 180-дневного или 365-дневного периода». ${ }^{92}$ Когда его спросили об этих числах, Кристенсен сослался на доклад СП, сказав: «Они не объясняют, что это означает, но насколько я могу просчитать, похоже, что силы США в Европе находятся в месячной готовности, Турция в годовой и другие принимающие страны - в шестимесячной готовности». ${ }^{93}$ Не имеет большого значения, насколько эти числа точны. На практике, даже лучше, что точную степень готовности трудно найти в публично доступных источниках. Однако, это не меняет факта наличия разрыва в способностях. Учитывая документально доказанное превосходство, которое Россия сохра-

92 Gene Aloise and John Pendleton, Nuclear Weapons: DoD and NNSA Need to Better Manage Scope of Future Refurbishments and Risks to Maintaining U.S. Commitments to NATO, GAO 11-387 report to congressional requesters (Washington DC: United States Government Accountability Office, 2011), 5-10, по состоянию на 4 апреля 2016, http://www.gao.gov/new.items/d11387.pdf.

93 Hans Kristensen, интервью автора, 1 апреля 2016. 
няет на восточном фланге, тактическая ядерная способность СДН вполне может оказаться единственным вариантом в случае непосредственного кризиса. Однако, если действительно НАТО требуются как минимум тридцать дней для подготовки самолетовылета для нанесения ядерного удара, тогда такой вариант не является реалистическим и тем более надежным.

Имея в виду время и расстояния в сценариях, которыми в потенциале располагает Россия, такой низкий уровень готовности не обеспечивает надежного сдерживания. Это область, в которой ядерная прозрачность невыгодна - НАТО должно засекретить уровни своей ядерной готовности. Время реакции в тридцать дней NORAD-а для США и Канады может быть излишеством, но тем не менее все эти уровни готовности должны быть повышены за рамки одного месяца, чтобы стать надежными. Однако, они не должны быть одинаковыми. Путем варьирования уровнями готовности, принимающие страны смогут поддерживать предсказуемое расписание, позволяющее необходимую подготовку и реконфигурирование сил. Между тем, повышенный уровень боеготовности даст способность Альянсу действовать при предупреждении с коротким сроком, и будет надежным сдерживающим фактором. С добавлением Турции и Польши, Альянс легко сможет поддерживать два формирования «высокой» готовности (меньше, чем сорок восемь часов), четыре “умеренной» готовности (меньше, чем тридцать дней) и одно формирование «низкой» готовности в любое время. Если индикации и предупреждения когда-нибудь заставят Альянс адаптировать эти уровни, его силы будут в состоянии выполнить задачу.

\section{\# 5: Создание «Фонда НАТО для стратегического сдерживания»}

Расходование денег, и конкретно, на ядерное сдерживание, касается всех трех факторов сдерживания: способностей, доверия и коммуникаций. Креативный проект американского бюджета на 2016 год может служить образцом для финансирования ядерного сдерживания, осуществляемого НАТО. Министр обороны США Эш Картер, выступая перед Комитетом Сената по вооруженным силам в марте 2016 года, первым публично поддержал идею создания фонда для ядерной модернизации. ${ }^{94}$ В теории, это уникальное предложение обеспечивает ассигнования на достижение желательных потенциалов и способностей ядерной триады, в то же время избегая возложение непосильного бремени на Военно-воздушные силы и Военно-морской флот. Согласно докладу Центра изучения проблем нераспространения имени Джеймса Мартина от января 2014, «в течении следующих тридцати лет Соединенные Штаты планируют израсходовать приблизительно \$1 триллион на поддержание нынешнего арсенала, приобре-

94 Aaron Mehta, "Carter Open to DoD-wide Nuclear Weapons Fund," Defense News, March 18, 2016, по состоянию на 4 апреля 2016, www.defensenews.com/story/ defense/policy-budget/budget/2016/03/18/carter-open-department-wide-nuclearweapons-fund/81972126/. 
тение замещающих систем и модернизацию существующих ядерных бомб и боеголовок». 95

Эта концепция «фонда стратегического сдерживания» могла бы обслуживать очень полезную и своевременную цель в рамках НАТО. Хорошо известные широкой публике финансовые вклады в НАТО на национальном уровне, внимание на которые недавно обратил Трамп, но что важнее - последние три министра обороны, становились слоном в посудной лавке на каждом саммите НАТО.

Применение этого "ядерного налога» ко всем двадцати восьми государствам дает возможность добиться реализации множества целей. В стратегическом плане оно позволяет Альянсу планировать и финансировать стратегическое сдерживание в следующих десятилетиях, независимо от того, подразумевает ли это ядерное оружие. На оперативном уровне, оно, во-первых, снимает денежное бремя финансирования миссий СДН, которое полностью лежит на плечах пяти принимающих стран. Эти миссии стоят дорого, связаны с расходами на постоянную модернизацию и/или замену стареющих СДН, обеспечение безопасности и хранения зарядов, подготовку, обучение и т.д. Такой фон также мог бы помочь США восстановить расходы в размере $\$ 10$ миллиардов на ППЖ В-61. ${ }^{96}$ И что наиболее важно, подобно следованию денежного следа, оставляемого террористами, иметь индивидуальное национальное финансирование ядерных программ дает государством право собственности над ядерными миссиями. В политическом плане, это заставляет страны провести давно откладываемые публичные дискуссии о том, что означает для общественности быть частью ядерного альянса - и стоит ли за это платить.

На практике, однако, те, кто должны наложить на себя такой «налог», а именно главы двадцати восьми государств, по всей видимости, никогда не одобрили бы такую концепцию. Наоборот, они, вероятно, укажут на факт, что отличные от США члены НАТО, как сказал бывший главнокомандующий союзными силами адмирал Джеймс Ставридис: «тратят на оборону в общей сумме \$300 миллиардов - больше, чем Россия и Китай вместе». Это потребует от США вести остальных за собой, а не подталкивать их сзади, наряду с ядерными Соединенным Королевством и Францией, чтобы направить Альянс в этом направлении в Варшаве. Даже если каждая страна внесет один евро в фонд, этот один евро станет поводом для бес-

95 Jon Wolfsthal, Jeffrey Lewis, and Marc Quint, The Trillion Dollar Nuclear Triad (Monterey, California: James Martin Center for Nonproliferation Studies, January 2014), по состоянию на 4 апреля 2016, https://www.nonproliferation.org/wpcontent/uploads/2016/04/140107_trillion_dollar_nuclear_triad.pdf.

96 Lewis, "A Steal at \$10 Billion."

97 Joseph J. Schatz and Benjamin Oreskes, "Europe to US: Ignore Donald Trump, we need NATO," Politico, April 1, 2016, по состоянию на 29 апреля 2016, http://www.politico.eu/article/europe-us-trump-we-need-nato-spending-militaryalliance-cuts-russia/. 
ценных дискуссий в парламентах и на публичной арене по вопросу об ассигновании денег на ядерные нужды. Конечным результатом станет открытая и честная дискуссия об ядерном альянсе и о том, желают ли отдельные страны платить за эту способность - даже если речь идет об одном евро.

\section{\# 6: Составление декларативного ядерного заявления НАTO}

Опубликованием четкого декларативного заявления НАТО оказало бы дальнейшее сдерживающее воздействие на своих потенциальных противников и вселило бы уверенность своим союзникам. Малкольм Чалмерс описывает ценность такого заявления следующим образом:

Действия говорят сильнее, чем слова, и факт, что ни одно государство не использовало ядерное оружие в течение более шестидесяти лет, говорит более красноречиво, чем любая декларативная политика. И всетаки, несмотря на этот факт - а может быть, в некоторой степени, благодаря ему, - заявления, которые делают государства о том, когда и в каких целях они могли бы использовать оружие, остается ключевым элементом в дискурсах сдерживания и разоружения. ${ }^{98}$

Декларативное заявление НАТО могло бы помочь открыть дверь к более прозрачным дискуссиям по ядерным вопросам внутри Альянса, а также и внутри руководств отдельных стран-членов. Так же, как после Холодной войны, так и после акций России в Крыму и на Украине, среда безопасности изменилась, и декларативное заявление НАТО должно отражать эти изменения. Точнее, заявление должно содержать положения, которые давали бы ясно понять, что «использование какой-либо ядерной риторики или ядерного принуждения во время кризиса незамедлительно изменит характер кризиса». Кроме того, в нем должно быть сказано, что «использование 'де-эскалирующих' ядерных ударов является неприемлемым поведением, которое немедленно изменит характер ситуации или конфликта».

Надо избежать опасности того, чтобы заявление было слишком ограничивающим, например, предлагая политику «Не использовать ядерное оружие первым». Это как раз та политика, от которой Россия отказалась в 2000 году. ${ }^{99}$ Такая политика не допускает возможности использовать ядерное оружие первым даже в момент, когда существование государства и его народа находится под непосредственной угрозой. В то же время, оно не должно быть слишком всеохватным, констатируя, что «единственной задачей» ядерного оружия является сдерживание противника от использования такого оружия, коей политики придерживаются Китай и Индия.

98 Malcolm Chalmers, Nuclear Narratives: Reflections on Declaratory Policy (London: Royal United Services Institute, 2010), 3, по состоянию на 4 апреля 2016, https://rusi.org/sites/default/files/201005_whr_nuclear_narratives_0.pdf.

99 Kroenig, The Renewed Russian Nuclear Threat and NATO Nuclear Deterrence Posture. 
Примером этого на практике было бы использование ядерного оружия для уничтожения ядерных сил другого государства с целью предотвратить их использование. Хотя упреждающий (не превентивный) удар может выглядеть логическим и уместным, почти невозможно отличить такой удар от разоружающего нападения первым. В конечном счете, четкое декларативное заявление по ядерному оружию, основанное на балансе безопасности и разоружения или нераспространения, подкрепленное политической волей двадцати восьми государств, имело бы большое значение. Как писал Чалмерс, «в дипломатии нормой является то, что самой искренней формой декларации является та декларация, которая повторяется часто и на самом высоком уровне». ${ }^{100}$ Слова имеют значение. Коммуникация есть один из "трех больших» факторов стратегии сдерживания. Нет более подходящего момента опубликовать сильное декларативное заявление, чтобы противодействовать российскому бряцанию ядерной саблей, чем на саммите в Варшаве.

Суть предложения: НАТО должно улучшить свою коммуникацию. Прежде всего, национальные лидеры должны высказаться и объяснить преимущества солидной ядерной политики и ядерной готовности. Информационные бюллетени НАТО не стоят ничего, если национальные политики не обоснуют перед общественностью необходимость изменений.

\section{Заключение}

В целом, в этой работе рассмотрена роль и будущее ядерного сдерживания, осуществляемого Североатлантическим Альянсом. Предложенные рекомендации касаются нескольких аспектов, в том числе военных способностей, политического доверия и стратегической коммуникации. Хотя рекомендации охватывают диапазон от стратегического до тактического уровня, все они направлены на улучшение целостного состояния сдерживания. Учитывая увеличивающуюся угрозу с востока и с юга, с которыми сталкивается Альянс, пришло крайнее время для Организации Североатлантического договора заняться пропусками и слабыми местами в своей стратегии ядерного сдерживания. Провал в этом деле подверг бы риску первейшую задачу Альянса, коллективную защиту.

По завершении Варшавского саммита в 2016 году НАТО должно заново определить и публично заявить, что означает быть «ядерным альянсом». Просто поддержание небольшого запаса тактических ядерных зарядов не оказывает сдерживающего эффекта на противников и не дает уверенности союзникам. На деле, иногда это создает нежелательные политические проблемы - как показало в 2009 году настойчивое требование Германии убрать это оружие, и затем неожиданный «поворот кругом» и требование оставить их пока. По общему признанию, ядерное сдерживание формирует только часть целостной стратегии сдерживания НАТО. Однако, это

${ }^{100}$ Chalmers, Nuclear Narratives, 8. 
оружие обеспечивало надежную трансатлантическую связь в течении более чем пятидесяти лет. Оно связывало свободу Европы с «высшей гарантией», данной США, обязательством воевать и погибнуть в ядерной войне, чтобы защитить эту свободу. Осуществление значительных изменений в позиции по ядерному сдерживанию будет, без всякого сомнения, делом трудным, но не невозможным. В любом случае, эта тема не сойдет с повестки дня - как отчаянно Альянс не желал бы не «иметь дело» с ядерным противником - потому что, в конце концов, противник всегда участвует в голосовании. На Варшавском саммите НАТО следует определить курс, подобный тому, который был определен инициативой ОССО в 2012 году: модернизировать ядерное сдерживание таким образом, чтобы четко коммуницировать его надежность (политическую волю) и военные способности любому потенциальному противнику сегодня или в будущем.

\section{Оговорка}

Для сбора данных о местонахождении и количестве ядерных зарядов автор использовал только несекретную информацию из открытых источников, и достоверность этих данных автором не проверялась. Здесь выражена точка зрения единственно автора, и данное мнение не отражает официальной политики или позиции Министерства военно-воздушных сил, Министерства обороны или правительства США.

\section{6 авторе}

Подполковник Мэтт Андерсон (ВВС США) является военным пилотом, командиром экипажа и старшим сотрудником Европейского центра стратегических исследований имени Джорджа К. Маршалла. 